Ekonomia - Wroclaw Economic Review 22/1 (2016)

Acta Universitatis Wratislaviensis

No 3731

DOI: 10.19195/ 2084-4093.22.1.3

Barbara Majewska-Jurczyk

Wyższa Szkoła Bankowa we Wrocławiu

bmajjur@gmail.com

\title{
Ochrona interesów konsumentów przed działaniami parabanków sprawowana przez Urząd Ochrony Konkurencji i Konsumentów
}

\author{
JEL Classification: D1 ( D18)
}

Keywords: financial market, consumer protection, parabanks, unfair advertising, contract patterns

\begin{abstract}
Protection of Consumers' Interests Against Quasi-banks Exercised by the Office of Competition and Consumer Protection

The article presents the problem of the functioning of parabanks in Poland and the role of the Office of Competition and Consumer Protection in consumer protection from parabanks unfair practicies on financial services market. The aim of the Office of Competition and Consumer Protection is the observation and prohibition of parabanks activities which are connected with high costs of loans and credits for consumers. Activities of parabanks are connected with the economic risk for consumers.
\end{abstract}

\section{Wstęp}

Artykuł 76 Konstytucji Rzeczypospolitej Polskiej stanowi, iż „władze publiczne chronią konsumentów, użytkowników i najemców przed działaniami zagrażającymi ich zdrowiu, prywatności i bezpieczeństwu oraz przed nieuczciwymi prakty-

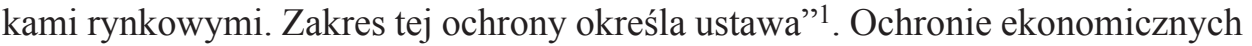
praw konsumentów w Polsce zostały poświęcone przepisy szeregu ustaw, które zostaną omówione w dalszej części artykułu.

1 Konstytucja Rzeczypospolitej Polskiej z dnia 2 kwietnia1997 roku, Dz.U. z 1997 r. Nr 78 , poz. 483 .

Ekonomia - Wroclaw Economic Review 22/1 (2016)

(C) for this edition by CNS 
Kontrola zachowań przedsiębiorców działających na rynku usług finansowych ma istotne znaczenie, stosują oni bowiem wobec konsumentów nieuczciwe praktyki grożące ryzykiem ekonomicznym. Pożyczki udzielane w tym segmencie rynku związane są z wysokimi kosztami dla klienta (opłatą przygotowawczą, opłatami windykacyjnymi itp.). Ponieważ konsumenci zajmują słabszą pozycję, szczególnie ekonomiczną, w transakcjach z profesjonalnymi uczestnikami gry rynkowej, deficyt ich wiedzy na rynku usług finansowych dotyczy zarówno etapu poprzedzającego zawarcie umowy, jak i całego okresu trwania stosunku zobowiązaniowego.

Usługi finansowe są przedmiotem szczególnego zainteresowania polityki konsumenckiej w Unii Europejskiej, a zatem i w Polsce, gdzie Urząd Ochrony Konkurencji i Konsumentów (UOKiK) na podstawie art. 1 ust. 1 ustawy o ochronie konkurencji i konsumentów (dalej ustawa) ${ }^{2}$ został upoważniony do ochrony interesów przedsiębiorców i konsumentów. Mające ostatnio miejsce antykonsumenckie praktyki stosowane przez parabanki w Polsce skłoniły UOKiK do wystąpienia z inicjatywą wprowadzenia w życie nowych przepisów dotyczących przede wszystkim rynku finansowego. Rolą Urzędu jest bowiem m.in., ochrona konsumentów w obszarze usług finansowych. Uchwalona w sierpniu 2015 r. ustawa o zmianie ustawy o ochronie konkurencji i konsumentów, która weszła w życie 17 kwietnia br., dotyczy zwiększenia skuteczności działań UOKiK w zakresie przeciwdziałania naruszeniom interesów konsumentów poprzez usprawnienie systemu eliminowania $\mathrm{z}$ obrotu niedozwolonych wzorców umów zawieranych z konsumentami, a więc takich postanowień, które w myśl art. 385 kodeksu cywilnego kształtują prawa i obowiązki konsumenta w sposób sprzeczny z dobrymi obyczajami, rażąco naruszając jego interesy. Nowelizacja ustawy wprowadza również rygor natychmiastowej wykonalności decyzji UOKiK, dokonywania prób zakupu kontrolowanego (np. podszywanie się pod klienta banku (parabanku) w celu sprawdzenia pod kątem niedozwolonych klauzul, zaproponowanej przez bank treści umowy), nakładania kar finansowych do $10 \%$ rocznego obrotu po stwierdzeniu niedozwolonej klauzuli, wydłużeniu z 1 do 3 lat okresu przedawnienia praktyk naruszających zbiorowe interesy konsumentów ${ }^{3}$.

Ochrona zbiorowych interesów konsumentów przewidziana w ustawie sprowadza się do uznania za sprzeczne z art. 24 ust. 1 takich działań przedsiębiorców, które polegają na:

- stosowaniu postanowień wzorców umów, które zostały wpisane do rejestru postanowień wzorców umów uznanych za niedozwolone,

- naruszenie obowiązku udzielania konsumentom rzetelnej, prawdziwej i pełnej informacji,

— nieuczciwe praktyki rynkowe lub czyny nieuczciwej konkurencji.

${ }^{2}$ Ustawa o ochronie konkurencji i konsumentów z dnia 16 lutego 2007 roku, Dz.U. Nr 50 z 2007 r., poz. 331.

3 Ustawa o zmianie Ustawy o ochronie konkurencji i konsumentów oraz niektórych innych ustaw z dnia 5 sierpnia 2015 roku, Dz.U. z 16.10.2015 poz.1634. 
Parabanki są instytucjami finansowymi wykonującymi czynności substytucyjne do czynności bankowych, które do 11 marca br. nie podlegały ustawie Prawo bankowe i nadzorowi finansowemu sprawowanemu przez Komisję Nadzoru Finansowego. Właśnie tego dnia weszły w życie przepisy ustawy z 5 sierpnia 2015 r. o zmianie ustawy o nadzorze nad rynkiem finansowym oraz niektórych innych ustaw, które wprowadzają istotne regulacje dotyczące np. pozaodsetkowych kosztów kredytu, których wartość dotychczas nie była ograniczona i mogły one wielokrotnie przewyższać naliczane odsetki. Nowa ustawa wyposażyła KNF w uprawnienia prowadzenia postępowań wyjaśniających przeciwko podmiotom, wobec których ma podejrzenie, iż wykonują działalność bankową niezgodną z prawem bankowym ani systemem gwarantowania depozytów ${ }^{4}$. Ponadto, KNF może kierować zawiadomienia do prokuratury o popełnieniu przestępstwa. Komisja Nadzoru Finansowego prowadzi też listę ostrzeżeń publicznych, będącą rejestrem podmiotów, do których ma podejrzenia, że przyjmują depozyty bez zezwolenia, a więc prowadzą działalność parabankową.

W literaturze przedmiotu nie spotykamy jednolitej definicji parabanków. Nie ulega wątpliwości, że są one instytucjami prowadzącymi działalność na rynku usług finansowych. Niektórzy autorzy ${ }^{5}$, stosując szeroką wykładnię tego pojęcia, uważają, iż terminem ,parabanki” można określić inne podmioty niż banki, które mogą, zgodnie z art. 5 ust. 5 ustawy Prawo bankowe, wykonywać czynności wymienione w ust. 1 wspomnianego przepisu. Należą do nich: spółdzielcze kasy zapomogowo-pożyczkowe, pracownicze kasy zapomogowo-pożyczkowe, spółdzielcze kasy oszczędnościowo-kredytowe, narodowe fundusze inwestycyjne, firmy leasingowe, towarzystwa ubezpieczeniowe, firmy oferujące pożyczki lub inwestycje kapitałowe itp. W węższym ujęciu parabanki to instytucje finansowe, które nie są bankami, ale gromadzą depozyty i udzielają pożyczek.

Należy zgodzić się z podanym przez W. Srokosza określeniem parabanków jako instytucji innych niż banki, wykonujących działalność depozytową jako działalność podstawową, która musi podlegać takim rygorom i ograniczeniom, aby nie zagrażało to bezpieczeństwu konsumentów oraz całemu rynkowi finansowemu ${ }^{6}$.

Wypada zatem zadać pytanie, jak rozumieć pojęcie ,parabank” w odniesieniu do ochrony konsumentów. Otóż w opinii autorki najbardziej adekwatnym określeniem jest: niebankowa firma pożyczkowa, ponieważ rola Urzędu Ochrony Konkurencji i Konsumentów w aspekcie działań tych firm ma na celu zadba-

${ }^{4}$ Ustawa z dnia 5 sierpnia 2015 roku o zmianie ustawy o nadzorze nad rynkiem finansowym oraz niektórych innych ustaw, Dz.U. z 2015 r. poz. 1357, 1830; oraz K. Waliszewski, Miejsce i rola parabanków w systemie finansowym i gospodarce, Warszawa 2012, s. 56.

${ }^{5}$ M. Bączyk et al., Prawo bankowe. Komentarz, Lex Polonica, komentarz do art. 5 ustawy Prawo bankowe, Warszawa 2007; W. Szpringer, Polskie regulacje bankowe. Perspektywa europejska, Warszawa 2000, s. 4; L. Góral, Instytucje parabankowe w ustawodawstwie wybranych krajów Unii Europejskiej i w Polsce, „Przegląd Ustawodawstwa Gospodarczego” 10, 1997.

6 W. Srokosz, Instytucje parabankowe w Polsce, Warszawa 2011, s. 79. 
nie o to, by zasady udzielania pożyczek pieniężnych oraz koszty ich egzekucji były przejrzyste i zrozumiałe dla konsumentów oraz by koszty pożyczek były jak najniższe. Nie ulega wątpliwości, że z punktu widzenia ochrony konsumentów istotne jest to, że niebankowe firmy pożyczkowe oferują konsumentom transakcje związane $\mathrm{z}$ ryzykiem finansowym.

Doceniając wagę problematyki ochrony interesów konsumentów w świetle przepisów prawa, a przede wszystkim działań UOKiK, autorka stara się w poniższym artykule pokazać (na podstawie analizy decyzji UOKiK oraz wyroków Sądu Ochrony Konkurencji i Konsumentów - SOKiK), iż wzmocnienie nadzoru państwa nad działalnością firm pożyczkowych stanowi skuteczną ochronę ekonomicznych praw konsumentów.

\section{Analiza praktyk stosowanych przez niebankowe firmy pożyczkowe naruszających ekonomiczne interesy konsumentów}

Urząd Ochrony Konkurencji i Konsumentów sprawuje nadzór nad działaniami przedsiębiorców, których skutkiem jest naruszenie zbiorowych interesów konsumentów na podstawie: ustawy o ochronie konkurencji i konsumentów, ustawy o kredycie konsumenckim, ustawy o przeciwdziałaniu nieuczciwym praktykom rynkowym oraz ustawy o zwalczaniu nieuczciwej konkurencji. Wspomniane akty prawne mają m.in. na celu ochronę ekonomicznych praw konsumentów. Wzmocnienie bezpieczeństwa ekonomicznego konsumentów polega na ochronie przed nieuczciwymi praktykami rynkowymi stosowanymi przez przedsiębiorców, a w szczególności przed jednostronnie niekorzystnymi umowami czy rygorystycznymi warunkami kredytowania oraz na naruszeniu obowiązku udzielania konsumentom rzetelnej, prawdziwej i pełnej informacji. Ponadto istotnym zadaniem UOKiK jest w tej kwestii kontrola i analiza niedozwolonych wzorców umów stosowanych przez niebankowe firmy pożyczkowe.

Działania Prezesa UOKiK oparte na ustawie o ochronie konkurencji i konsumentów podejmowane w interesie publicznym mają na celu ochronę interesów ogółu konsumentów, a nie poszczególnych uczestników rynku. Ustawa o kredycie konsumenckim z 12 maja 2011 r. jest jednym z najistotniejszych aktów prawnych w Polsce mającym zastosowanie do niebankowych firm pożyczkowych, z uwagi na to że obejmuje wyczerpująco swoim zakresem działalność prowadzoną przez te podmioty. Rola UOKiK w egzekwowaniu postanowień wspomnianej ustawy sprowadza się do analizy wzorców umów pod kątem naruszenia w szczególności obowiązków informacyjnych, stosowania niedozwolonych postanowień umownych, nieuczciwych praktyk rynkowych oraz naruszenia ustawy o zwalczaniu nieuczciwej konkurencji ${ }^{7}$.

7 Ustawa o kredycie konsumenckim, Dz.U. Nr 126 z 2011 r. poz. 715, z późn. zm.

Ekonomia - Wroclaw Economic Review 22/1 (2016)

(C) for this edition by CNS 
Jak wspomniano, art. 24 ust. 1 i 2 ustawy o ochronie konkurencji i konsumentów uznaje za praktykę naruszającą zbiorowe interesy konsumentów stosowanie postanowień wzorców umów, które zostały wpisane do rejestru wzorców umów niedozwolonych. Firmy pożyczkowe naruszają wspomniany przepis, stosując przy udzielaniu kredytów konsumentom identyczne klauzule jak wpisane do rejestru niedozwolonych postanowień umownych. W wyroku z 2005 r. Sąd Ochrony Konkurencji i Konsumentów (SOKiK) wyjaśnił, że naruszenie zbiorowych interesów konsumentów ma miejsce również w sytuacji, gdy przedsiębiorca stosuje w umowie z konsumentem klauzule mające zbliżoną treść do klauzul zakazanych i które wywołują te same skutki co klauzule wpisane do rejestru niedozwolonych klauzul umownych ${ }^{8}$.

W roku 2015 Sąd Ochrony Konkurencji i Konsumentów rozpatrywał apelację Polskiej Korporacji Finansowej Skarbiec (obecnie Pożyczka Gotówkowa sp. z.o.o w Warszawie) przeciwko Prezesowi Urzędu Ochrony Konkurencji i Konsumentów, który uznał, że firma dopuściła się praktyki naruszającej zbiorowe interesy konsumentów, polegającej na udzielaniu i rozpowszechnianiu konsumentom nieprawdziwych i wprowadzających w błąd informacji oraz pobieraniu opłaty przygotowawczej wyższej niż 5\% udzielonej pożyczki. SOKiK w powyższej sprawie był zdania, że informacje na temat całkowitego kosztu kredytu i rzeczywistej rocznej stopy oprocentowania podawane przez Skarbiec były dla konsumentów nieczytelne i niezrozumiałe, wobec czego konsumenci nie mogli dokonać obiektywnej oceny oferty tego przedsiębiorcy, a zatem nie mogli jej porównać z ofertami innych kredytodawców ${ }^{9}$. Sąd Apelacyjny podtrzymał decyzję UOKiK oraz wyrok SOKiK, uznając, iż Skarbiec naruszył przepisy ustawy o ochronie konkurencji i konsumentów oraz ustawy o kredycie konsumenckim. Podobne stanowisko zajął w 2015 r. UOKiK w decyzji w sprawie przeciwko spółce Profi Credit Poland, co do której zastrzeżenia Prezesa dotyczyły stosowanej wobec konsumentów opłaty przygotowawczej, pobieranej w celu zrekompensowania kosztów czynności związanych z przygotowaniem do zawarcia umowy. Opłata wymagana przez Profi Credit była oderwana od wartości kosztów wynikających ze świadczeń realizowanych na rzecz konsumentów, co godziło w zasadę ekwiwalentności świadczeń. Wobec powyższego, UOKiK uznał, że działanie spółki zagrażało interesom konsumentów ${ }^{10}$.

Zarówno UOKiK, jak SOKiK kontrolują wzorce umów zawieranych przez firmy pożyczkowe. W świetle art. 385 kodeksu cywilnego (k.c.) niedozwolone postanowienia umowne zawierane $\mathrm{z}$ konsumentem to takie, które nie są uzgodnione indywidualnie, jeżeli kształtują jego prawa i obowiązki w sposób sprzeczny $\mathrm{z}$ dobrymi obyczajami, rażąco naruszając jego interesy ${ }^{11}$. Przedmiotem analizy

\footnotetext{
8 Wyrok SOKiK z dnia 25 maja 2005 r., sygn. akt XVII AmA 46/04.

9 Wyrok SOKiK z dnia 10 lutego 2015 r., sygn. akt VI ACa 591/14.

${ }_{10}$ Decyzja UOKiK z dnia 30 grudnia 2015 r., nr RKT-21/2015.

11 Wyrok SOKiK z dnia 26 marca 2010 r., sygn. akt XVII AmC 1162/09.
} 
UOKiK w sprawach odnoszących się do stosowania niedozwolonych wzorców umów są postanowienia zawarte w umowach z konsumentami dotyczące sposobu naliczania kosztów windykacyjnych, spłaty zadłużenia, przewidujące rażąco wygórowaną karę umowną, zastrzegające opłaty w wygórowanej wysokości czy przewidujące opłatę za zawiadomienie o wypowiedzeniu umowy.

Postanowienia zawarte $\mathrm{w}$ umowach $\mathrm{z}$ konsumentami $\mathrm{w}$ aspekcie ponoszenia przez nich kosztów windykacyjnych są, zdaniem UOKiK, niedozwolone, z uwagi na to że na przykład w sposób niedostatecznie precyzyjny określają zasady, na podstawie których firma pożyczkowa może podejmować działania windykacyjne. Są to na przykład postanowienia, w których nie zapewnia się konsumentowi stosownego czasu na spłatę pożyczki, a tym samym nie będzie on miał możliwości podjęcia działań zmierzających do uregulowania długu, czy postanowienia, w których w umowie określa się maksymalną wysokość opłat za wykonywane czynności windykacyjne ${ }^{12}$. Jak zauważa Prezes UOKiK, wysokość opłat za czynności windykacyjne powinna odzwierciedlać rzeczywiste koszty tych czynności, a tymczasem w kwestionowanych postanowieniach firmy pożyczkowe zastrzegły opłatę za czynność, która nie musi wiązać się z ponoszeniem jakichkolwiek kosztów ${ }^{13}$.

Niedozwolonym postanowieniem umownym są również rygorystyczne wymogi spłaty zadłużenia polegające na przykład na konieczności podania przez konsumenta przy spłacie pożyczki numeru PESEL, co jest to w opinii UOKiK, zabronione w świetle art. 385(1) k.c. Podobnie, zawarte w umowie z konsumentem postanowienia o możliwości nałożenia przez firmę pożyczkową nadmiernie wygórowanej kary umownej w sposób rażący naruszają interesy ekonomiczne konsumentów. Jak zauważa UOKiK, wysokość ponoszonej kary umownej musi przyjmować racjonalne granice i nie może stanowić źródła dodatkowego zysku dla pożyczkodawcy, a ponadto taka kara nie powinna wiązać się z poniesioną przez firmę szkodą ${ }^{14}$.

Jeżeli firma pożyczkowa wpisuje do umowy klauzule dotyczące wprowadzenia zmian niekorzystnych dla konsumenta, na przykład możliwość dokonania zmiany wysokości opłat lub zasad ich stosowania i naliczenia, a więc zmiany dokonane według jej uznania, to, w opinii UOKiK, umowa taka narusza art. 385(1) k.c. W 2013 r. UOKiK zakazał Baltic Money stosowania opłaty przygotowawczej, której wysokość nie odpowiadała wartości świadczeń realizowanych w ramach tej opłaty. Urząd zauważył w wydanej decyzji, że Baltic Money zgodnie z zawartą z konsumentami umową pobiera opłatę w wysokości $6 \%$ wnioskowanej kwoty kredytu, a więc w jej ramach mieszczą się inne opłaty, jak pobierane za rozpatrzenie wniosku kredytowego, ocenę ryzyka kredytowego czy czynności związane z uruchomieniem środków

12 Raport UOKiK z dnia 6 października 2013 r., Opłaty stosowane przez instytucje parabankowe.

13 Ibidem.

14 Raport UOKiK, s. 47.

Ekonomia - Wroclaw Economic Review 22/1 (2016)

(C) for this edition by CNS 
finansowych. W takiej sytuacji pobieranie dodatkowej opłaty przygotowawczej jest sprzeczne z prawem i godzi w interesy ekonomiczne konsumentów ${ }^{15}$.

Jeżeli przedsiębiorcy niebędący bankami i świadczący konsumentom usługi finansowe stosują praktyki naruszające zbiorowe interesy konsumentów, a mianowicie stosują dodatkowe opłaty przygotowawcze, których wysokość nie odpowiada wartości świadczeń realizowanych w ramach tych opłat (np. spółka Provident Polska S.A. ustalała opłaty w zależności od kwoty udzielanej pożyczki — im wyższa pożyczka, tym wyższa opłata za obsługę pożyczki), naruszają art. 3 ust. 1 ustawy o zwalczaniu nieuczciwej konkurencji, a ich działania uznane są przez UOKiK za sprzeczne z prawem ${ }^{16}$.

Wypowiedzenie umowy pożyczki przez pożyczkodawcę usankcjonowane wymogiem pokrycia kosztów przez konsumentów związanych ze złożeniem oświadczenia o wypowiedzeniu jest naruszeniem prawa sprzecznym z dobrymi obyczajami i takie postanowienie zawarte w umowie jest niedozwolone. Podobnie, za praktykę naruszającą zbiorowe interesy konsumentów UOKiK uznał działanie przedsiębiorcy (wspomnianej firmy pożyczkowej Baltic Money) polegające na obciążeniu konsumentów, w przypadku rozwiązania umowy, nadmiernie wygórowanymi kosztami ${ }^{17}$.

Praktyka pokazuje, że niebankowe firmy pożyczkowe nagminnie wprowadzają konsumentów w błąd co do warunków oferowanych im pożyczek, naruszając przepisy ustawy o przeciwdziałaniu nieuczciwym praktykom rynkowym ${ }^{18}$, która w art. 5(1) stanowi, iż ,praktykę rynkową uznaje się za działanie wprowadzające w błąd, jeżeli działanie to w jakikolwiek sposób powoduje lub może powodować podjęcie przez przeciętnego konsumenta decyzji dotyczącej umowy, której inaczej by nie podjął".

Wprowadzenie konsumenta w błąd przy udzielaniu pożyczki polega na podawaniu mu nieprawdziwych informacji dotyczących: rzeczywistej rocznej stopy oprocentowania (RRSO), całkowitej kwoty kredytu, całkowitego kosztu kredytu, całkowitej kwoty do zapłaty.

Pomiędzy ustawą o przeciwdziałaniu nieuczciwym praktykom rynkowym a ustawą o kredycie konsumenckim ${ }^{19}$ istnieje ścisła współzależność w interpretacji takich pojęć, jak: „całkowity koszt kredytu”, „,ałkowita kwota kredytu”, „RRSO”. Zgodnie z art. 5(6) u.k.k. w skład całkowitego kosztu kredytu, który konsument zobowiązany jest ponieść w związku z umową o kredyt, wchodzą: odsetki, opłaty, prowizje, podatki i marże, jeżeli są znane kredytodawcy, oraz koszty usług dodat-

15 Decyzja UOKiK z dnia 20 listopada 2013 r. nr RGD-61-12/13/MLM.

16 Decyzja UOKiK z dnia 20 kwietnia 2015 r. nr RWA-2/2015, RWA-61-5/13/AŻ.

17 Ibidem.

18 Ustawa o przeciwdziałaniu nieuczciwym praktykom rynkowym z dnia 23 sierpnia 2007 r., Dz.U. Nr 171, poz. 1206.

19 Ustawa o kredycie konsumenckim z dnia 12 maja 2011 r., Dz.U. z 2014 r., poz. 1497, 1585, 1662. 
kowych w przypadku, gdy ich poniesienie jest niezbędne do uzyskania kredytu. Całkowita kwota kredytu zawiera w sobie sumę wszystkich środków pieniężnych, które kredytodawca udostępnia konsumentowi na podstawie umowy o kredyt, a całkowita kwota do zapłaty przez konsumenta jest to suma całkowitego kosztu kredytu i całkowitej kwoty kredytu. Natomiast rzeczywista roczna stopa oprocentowania (RSSO) stanowi całkowity koszt kredytu ponoszony przez konsumenta, wyrażony jako wartość procentowa całkowitej kwoty kredytu w stosunku rocznym art. 5(12). Ustawa o kredycie konsumenckim jest głównym aktem prawnym normującym zagadnienia z zakresu stosowania przez firmy pożyczkowe nieuczciwych klauzul umownych przy udzielaniu kredytów, która w art. 30 podaje wymogi umowy o kredyt konsumencki. Konsument powinien zostać dokładnie poinformowany, w szczególności o parametrach kredytu (stopie oprocentowania oraz warunkach jej zmiany, rzeczywistej rocznej stopie oprocentowania oraz całkowitej kwocie do zapłaty przez konsumenta ustalonej w dniu zawarcia umowy, zasadach i terminach spłaty kredytu, skutkach braku płatności, prawa spłaty kredytu przed terminem itp.)

W praktyce, jak wynika z raportu oraz decyzji UOKiK, firmy pożyczkowe naruszyły art. 30 u.k.k. poprzez niepodawanie konsumentom rzetelnych informacji odnośnie do czasu obowiązywania umowy, prawa konsumenta do spłaty kredytu przed terminem, niewskazania terminu wypłaty kredytu, braku informacji o stopie oprocentowania kredytu oraz warunkach jej zmiany, nieprzekazywaniu konsumentom informacji o innych kosztach kredytu, niewskazania odsetek należnych w stosunku dziennym przy odstąpieniu od umowy. W opinii Urzędu naruszeniem art. 24 ust. 1 i 2 ustawy o ochronie konkurencji i konsumentów jest nie tylko wykazanie, że dana praktyka ma miejsce, lecz także, że potencjalnie istniało zagrożenie n a r u s z e n i a interesów konsumentów, na przykład wskutek niedopełnienia określonego obowiązku informacyjnego względem konsumentów, a więc nie jest konieczne rzeczywiste wystąpienie negatywnego skutku w praktyce. Oznacza to, że wystarczy samo zaniechanie udzielenia przez przedsiębiorcę istotnych informacji, nawet jeżeli w praktyce nie zaistniały przesłanki wykorzystania tej informacji, na przykład określającej prawo konsumenta do spłaty kredytu przed terminem ${ }^{20}$. Przykładem na zaniechanie zamieszczenia w umowie z konsumentami informacji o opłacie za obsługę pożyczki w domu, podawaniu nieprawdziwej informacji o RRSO oraz o całkowitym koszcie kredytu jest decyzja wydana przez UOKiK w sprawie spółki Euro Providus S.A. Podane praktyki stosowane przez spółkę Urząd uznał za bezprawne i zgodnie z art. 26 ust. 1 ustawy o ochronie konkurencji i konsumentów nakazał zaniechania ich stosowania $\mathrm{w}$ terminie dwóch miesięcy ${ }^{21}$. Podobnie za praktykę naruszającą zbiorowe interesy konsumentów UOKiK uznał nieinformowanie przez Fundusz Pożycz-

20 Decyzja UOKiK z dnia 2 czerwca 2014 r., nr RKT-61-05/14/BP.

21 Decyzja UOKiK z 2015 r., nr RŁO 3/2015, RŁO -61-11/13/AM. 
kowy Pro-Biznes w umowach pożyczki o RSO, rocznej stopie oprocentowania zadłużenia przeterminowanego, sposobie i skutkach odstąpienia konsumenta od umowy, zamieszczanie we wzorach oświadczeń o odstąpieniu od umowy nierzetelnych i niepełnych informacji wskazujących, że w związku z odstąpieniem od umowy konsument zobowiązany jest do niezwłocznego zwrotu kwoty pożyczki oraz prowizji za udzielenie pożyczki, co jest sprzeczne z art. 54 ust. 1, 2 i 4 Ustawy o kredycie konsumenckim ${ }^{22}$. W wydanej decyzji UOKiK podniósł, że nierzetelne informacje podane konsumentowi wpływają na zakres poinformowania go o przyznanym mu uprawnieniu, sposobie jego wykonania i wynikających z tego skutków, w szczególności dotyczących praw i obowiązków stron.

Niebankowe firmy pożyczkowe naruszają również dalsze postanowienia ustawy o kredycie konsumenckim, a mianowicie art. 48, 49 oraz 50 przez zawarcie w umowach z konsumentami zapisów dotyczących na przykład wymogu poinformowania pożyczkodawcy co najmniej na 3 dni przed dokonaniem zwrotu pożyczki przed terminem, co jest sprzeczne $\mathrm{z}$ art. 48 u.k.k., na mocy którego konsument ma prawo w każdym czasie do spłaty całości lub części kredytu przed terminem określonym w umowie (ust. 1) oraz kredytodawca nie może uzależniać wcześniejszej spłaty kredytu od poinformowania go przez konsumenta (art. 48 u.k.k.). W świetle zapisu art. 49 u.k.k. konsument, spłacając kredyt przed terminem określonym w umowie, nie powinien płacić kosztów całości kredytu, całkowity koszt kredytu ulega bowiem obniżeniu o koszty dotyczące okresu, o który skrócono czas obowiązywania umowy, mimo że konsument mógł ponieść te koszty przed spłatą. Ponadto, na mocy art. 49 (2) u.k.k. kredytodawca może uzależnić spłatę kredytu przed terminem od zapłaty prowizji, której wysokość nie może przekraczać 1\% spłacanej części kredytu, jeżeli okres między datą spłaty kredytu a terminem spłaty kredytu przekracza 1 rok, jeżeli natomiast nie przekracza roku, prowizja za spłatę kredytu przed terminem nie może przekraczać $0,5 \%$ spłacanej części kwoty kredytu (art. 50(2), (3) u.k.k.). Prowizja nie może być wyższa niż wysokość odsetek, które konsument byłby zobowiązany zapłacić w okresie między spłatą kredytu przed terminem, a uzgodnionym terminem zakończenia umowy a także nie może być wyższa niż bezpośrednie koszty kredytodawcy związane $\mathrm{z}$ tą spłatą (art. 50(4)).

Niedozwolonym, a stosowanym przez firmy pożyczkowe postanowieniem umownym jest możliwość zastrzeżenia w umowie z konsumentem naliczenia odsetek za zwłokę spłaty pożyczki. OK Money zamieścił w umowie pożyczki obowiązek zapłaty przez konsumentów od 30 do 50 PLN za przesłanie wezwania do zapłaty w zależności od upływu terminu spłaty pożyczki. Takie klauzule zawarte w umowie pożyczki w ocenie UOKiK i SOKiK są niedozwolone i mogą powo-

22 Decyzja UOKiK z dnia 28 lipca 2015 r., nr RPZ 7/2015. 
dować, iż konsument zostanie obciążony opłatą niemającą związku z wydatkami i kosztami wynikającymi z czynności, za które jest pobierana ${ }^{23}$.

Zbyt często naruszanym przez firmy pożyczkowe aktem prawnym jest również ustawa o zwalczaniu nieuczciwej konkurencji ${ }^{24}$, która w art. 3(1) stanowi, że czynem nieuczciwej konkurencji jest działanie sprzeczne z prawem lub dobrymi obyczajami, jeżeli zagraża lub narusza interes innego przedsiębiorcy lub klienta. W zakresie poszanowania dobrych obyczajów z decyzji UOKiK i orzecznictwa SOKiK wynika wymóg przedsiębiorców okazywania szacunku względem konsumentów. Rozumowanie to prowadzi do stwierdzenia, iż sprzeczne z dobrym obyczajem jest na przykład nierzetelne udzielanie informacji konsumentom ${ }^{25}$. Podobnie, w doktrynie spotyka się wyjaśnienie pojęcia dobrych obyczajów, które odnosi się do obowiązku informowania partnera o istotnych (z jego punktu widzenia) okolicznościach dotyczących przedmiotu świadczeń, a także powinność czynienia tego w sposób prawdziwy, rzeczowy i kompetentny, co jest cechą generalną prawa umów i wypływa z obowiązku lojalnego kontraktowania ${ }^{26}$. Sąd Najwyższy w 2011 r. zwrócił uwagę, że traktowanie konsumentów przez przedsiębiorców przedmiotowo jest przekroczeniem granic działania przyzwoitego i godziwego ${ }^{27}$.

Czyny nieuczciwej konkurencji, których dopuszczały się niebankowe firmy pożyczkowe, polegały na stosowaniu opłat, których wysokość oderwana była od rzeczywistej wartości świadczeń, w zamian za które są pobierane. Przykładem może posłużyć sytuacja, w której pożyczkodawca pobiera opłatę za ratę pożyczki w domu konsumenta. $Z$ analizowanych przez UOKiK spraw wynika, iż kredytodawcy różnicują wysokość opłat za odbiór rat pożyczki w domu w zależności od kwoty pożyczki (im wyższa jest kwota pożyczki, tym wyższa opłata za obsługę w domu konsumenta). Kwota ta, w opinii UOKiK, powinna być identyczna dla wszystkich pożyczek o tej samej liczbie rat, a skoro konsument decyduje się na skorzystanie z dodatkowej usługi, jaką jest odbiór pożyczki w domu, powinien, zdaniem Urzędu, mieć pewność, że wynagrodzenie za dodatkową usługę odpowiada jej wartości. Jeżeli tak nie jest, to zachowanie pożyczkodawcy narusza dobre obyczaje i zbiorowe interesy konsumentów ${ }^{28}$.

Kontrola działań firm pożyczkowych przez Urząd Ochrony Konkurencji i Konsumentów polega na wszczęciu z urzędu postępowania wyjaśniającego w celu oceny, czy wzorce umowne stosowane przez przedsiębiorców zawierają niedozwolone postanowienia umowne, a więc czy ma miejsce naruszenie chronionych prawem interesów konsumentów. W 2014 r. UOKiK, rozpatrując

23 Decyzja UOKiK nr RBG-20/2014, RBG-61-15/13/JM.

24 Ustawa z dnia 16 kwietnia 1993 r. o zwalczaniu nieuczciwej konkurencji, Dz.U. z 1993 r. Nr 47, poz. 211, z późn. zm.

25 Wyrok Sądu Apelacyjnego z dnia 31 lipca 1995 r., sygn. akt I ACr 308/95.

26 E. Łętowska, Prawo umów konsumenckich, Warszawa 2002, s. 215-216.

27 Wyrok SN z dnia 4 listopada 2011 r., sygn. akt I CSK 796/10.

28 Raport UOKiK. 
działania firmy Optima SA, która nie będąc bankiem, świadczyła konsumentom usługi finansowe i dopuściła się naruszenia ustawy o kredycie konsumenckim $\mathrm{w}$ zakresie m.in.: niepodawania $\mathrm{w}$ formularzu informacyjnym dotyczącym kredytu konsumenckiego informacji o wysokości stopy oprocentowania zadłużenia przeterminowanego, podawaniu nieprawdziwej informacji o całkowitej kwocie do zapłaty poprzez nieuwzględnienie w niej kosztu opłaty za obsługę w miejscu zamieszkania oraz kosztu ubezpieczenia spłaty pożyczki, wprowadzaniu w błąd co do proporcji pomiędzy całkowitym kosztem kredytu a całkowitą kwotą kredytu, stosowaniu opłaty wstępnej, której wysokość nie odpowiada wartości świadczeń realizowanych w ramach tej opłaty, uzależnieniu przyjęcia od konsumenta wniosku o udzielenie pożyczki od jednoczesnego wyrażenia zgody na przesyłanie informacji handlowych drogą elektroniczną ${ }^{29}$. Powyższa decyzja pokazuje, iż Urząd przez udowodnienie i stwierdzenie, że spółka stosowała praktyki naruszające ekonomiczne interesy konsumentów, nakłada na nią karę pieniężną i nakazuje zaniechanie stosowania wspomnianych powyżej praktyk.

\section{Rola UOKiK w ochronie konsumentów przed szkodliwymi działaniami niebankowych firm pożyczkowych w zakresie reklamy pożyczek oferowanych konsumentom}

Z uwagi na fakt, że instytucje pozabankowe udzielają konsumentom rocznie pożyczek na kwotę od dwóch do trzech miliardów złotych ${ }^{30}$, celem działań UOKiK jest wykrywanie nieprawidłowości występujących jeszcze na etapie przed zawieraniem przez konsumentów umów, co ma zwiększyć stopień ich ochrony ${ }^{31}$.

Istotną rolę $\mathrm{w}$ zachęcaniu konsumentów do zaciągania pożyczek w niebankowych firmach pożyczkowych stanowi reklama pojawiająca się w środkach masowego przekazu, prasie, na plakatach i bilbordach. W opinii UOKiK kontrola reklam oznacza analizę każdej informacji skierowanej do nieoznaczonego kręgu odbiorców niezależnie od tego, czy zawiera jakąkolwiek bezpośrednią zachętę do wzięcia pożyczki lub do stawienia się w biurze firmy pożyczkowej albo nawiązania kontaktu w inny sposób, czy też takiej zachęty wprost nie zawiera. Chodzi tu przede wszystkim o możliwość wpływu zawartych tam treści na decyzje konsumentów ${ }^{32}$.

29 Decyzja UOKiK nr RBG-10/2014, RBG-61-20/13/KL.

30 M. Bednarek, M. Samcik, Parabanki rosna w site, www.wyborcza.biz z dnia 15.08.2012.

31 Urząd Ochrony Konkurencji i Konsumentów, Raport z kontroli reklam pozabankowych instytucji finansowych oferujących pożyczki konsumentom, Warszawa 2013.

32 Ibidem, s. 8. 
Zakaz reklam wprowadzających konsumentów w błąd wynika z przepisów: ustawy o przeciwdziałaniu nieuczciwym praktykom rynkowym z 2007 r., ustawy o kredycie konsumenckim z 2011 r. oraz ustawy o zwalczaniu nieuczciwej konkurencji z $1993 \mathrm{r}$.

Z przeprowadzonej przez UOKiK kontroli reklam trzydziestu siedmiu instytucji pożyczkowych w 2013 r. wynika, iż oferują one konsumentom krótkoterminowe pożyczki na niewielkie kwoty (czego nie oferują banki). Reklama stosowana przez instytucje pozabankowe nie może, w świetle przepisu art. 2 pkt 3 i 4 u.p.n.p.r., być sprzeczna z dobrymi obyczajami i w istotny sposób zniekształcać zachowanie rynkowe przeciętnego konsumenta przed zawarciem umowy dotyczącej produktu, w trakcie jej zawierania lub po jej zawarciu. Jak podniósł Sąd Ochrony Konkurencji i Konsumentów ${ }^{33}$ : , istotą pojęcia »dobry obyczaj« jest szeroko pojęty szacunek dla drugiego człowieka, który w stosunkach z konsumentami powinien wyrażać się właściwym informowaniem o przysługujących im uprawnieniach, niewykorzystywaniu uprzywilejowanej pozycji profesjonalisty i rzetelnym traktowaniu partnerów umów. Za sprzeczne z dobrymi obyczajami można uznać działania zmierzające do niedoinformowania, dezorientacji, wywołania błędnego przekonania u konsumenta, a także wykorzystywanie jego niewiedzy i naiwności" 34 . Konsument może być wprowadzony w błąd przez działanie lub zaniechanie oznaczające, że przedsiębiorca może rozpowszechniać prawdziwe lub nieprawdziwe informacje, które powodują mylne wyobrażenie o cechach produktu lub usługi. Zgodnie z art. 5 ust. 1 u.p.n.p.r. (powyżej wspomnianym) konsument może być wprowadzony w błąd, jeżeli działanie to w jakikolwiek sposób powoduje lub może powodować podjęcie przez przeciętnego konsumenta decyzji dotyczącej umowy, której inaczej by nie podjął.

Przekazy reklamowe niezwykle często wprowadzają konsumentów w błąd, szczególnie chodzi tu o sugestie zawarte w reklamach, jak reklama sugerująca, że firma pożyczkowa nie bada zdolności kredytowej: „Bez BIK” (Biuro Informacji Kredytowej). Przeciętny konsument nie zdaje sobie sprawy z tego, że ustawa o kredycie konsumenckim nakłada na kredytodawców bezwzględny obowiązek oceny ryzyka kredytowego $\mathrm{w}$ związku z udzielanym kredytem ${ }^{35}$. Z przeprowadzonej przez UOKiK kontroli reklam sześć z dziewięciu badanych pożyczkodawców opiera się przy udzielaniu kredytów na informacjach uzyskanych przez konsumentów oraz z BIG (Biuro Informacji Gospodarczej, którego baza jest znaczenie szersza niż $\mathrm{BIK})^{36}$. Oznacza to, że konsumenci mogą mieć przeświadczenie, że firma, udzielając im pożyczek, nie ocenia ryzyka kredytowego i w związku z tym otrzymają pożyczkę. Takie wprowadzenie konsumenta w błąd w reklamie może wywołać

33 Wyrok SOKiK z dnia 23 lutego 2005 r., akta sprawy Ama 118/04.

34 Ibidem.

35 Ustawa o kredycie konsumenckim, art. 5(16).

36 Raport UOKiK z kontroli reklam, s. 21; decyzja UOKiK nr RWR 61-29/12/ZR z dnia 31 grudnia $2013 \mathrm{r}$. 
u niego błędne przekonanie o pewności uzyskania kredytu, co stanowi niedozwoloną praktykę rynkową określoną $\mathrm{w}$ art. 4 ust. 1 i $2 \mathrm{w}$ związku $\mathrm{z}$ art. 5 ust. 1 u.p.n.p.r.

Innym naruszeniem prawa wynikającym $\mathrm{z}$ art. 7(1) $\mathrm{w}$ związku $\mathrm{z}$ art. 5 ust. 1 i 2 pkt 1 ustawy o kredycie konsumenckim w związku z art. 4 ust 1 i 2 ustawy o przeciwdziałaniu nieuczciwym praktykom rynkowym jest posługiwanie się w reklamie hasłami wskazującymi o wyjątkowości oferty danego pożyczkodawcy, jak ,najtańsza oferta pożyczek pozabankowych na rynku", jaką zamieścił na profilu internetowym Pronifet, czy reklama Wonga — „98\% klientów, którzy skorzystali z innych pożyczkodawców, oceniają Wonga lepiej”. Również za postępowanie naruszające zbiorowe interesy konsumentów uznał UOKiK zachowanie spółki Wonga, która w reklamach telewizyjnych oraz reklamach upowszechnianych w Internecie poprzez VOD podawała informacje dotyczące kosztu kredytu, a mianowicie stopy oprocentowania kredytu, rzeczywistej rocznej stopy oprocentowania, czasu obowiązywania umowy oraz całkowitej kwoty do zapłaty przez konsumenta, a także wysokości rat w sposób uniemożliwiający ich odczytanie z uwagi na wielkość czcionki oraz krótki czas ich prezentacji, co stanowiło naruszenie przepisów ustawy o kredycie konsumenckim i ustawy o ochronie konkurencji i konsumentów. Brzmienie sześciu spotów prezentowanych w reklamach naruszyło więc obowiązek przez spółkę Wonga.pl udzielania konsumentom rzetelnej, prawdziwej i pełnej informacji ${ }^{37}$. Ferratum Poland Sp. z o.o. zamieściła w swojej reklamie hasło: „wczasy gratis dla każdej pożyczki”, podczas gdy na reklamach wraz z informacją podaną bardzo drobną czcionką zostało napisane: „w trakcie promocji każdy klient otrzyma gratis bon promocyjny upoważniający do 7 noclegów dla 2 osób w wybranym hotelu. Minimalna pożyczka upoważniająca do otrzymania bonu to 100 zł. Czas promocji ograniczony, decyduje data złożenia wniosku o pożyczkę Expres Kasa". UOKiK podniósł w badanej sprawie, że tak sformułowany przekaz może wprowadzić konsumenta w błąd przez nieprzekazanie przez pożyczkodawcę w sposób jasny istotnych informacji dotyczących pożyczki, co stanowi zakazaną praktykę z ustawy o przeciwdziałaniu nieuczciwym praktykom rynkowym ${ }^{38}$. W obu przypadkach UOKiK uznał reklamy za sprzeczne z prawem, sugerowały bowiem konsumentom znacznie lepsze oferty, niż mieli konkurenci ${ }^{39}$. Wprowadzenie konsumentów w błąd miało również miejsce, gdy firma pożyczkowa OK Money zawarła w swojej reklamie stwierdzenie: ,proces ubiegania się o pożyczkę w OK Money spełnia najwyższe standardy systemu bankowego", co sugeruje, że takie hasło ma zachęcić do skorzystania z usług tej spółki poprzez stworzenie wrażenia, iż jest instytucją działającą jak bank, a więc w odczuciu konsumenta ubieganie się o taką pożyczkę będzie bezpieczne i nie stworzy jakiegokolwiek ryzyka. Ponadto, jak zauważa UOKiK, pozabankowa instytucja finansowa nie jest związana tajemnicą bankową, nie sposób zatem uznać, że spółka OK Money

37 Decyzja UOKiK z dnia 17 grudnia 2015 r. Ne RKT-16/2015.

38 Ibidem.

39 Raport UOKiK, s. 23. 
w kwestii poufności danych kieruje się standardami obowiązującymi w systemie bankowym ${ }^{40}$. Pozostałe reklamy wprowadzające konsumentów w błąd zawierały hasła mijające się z prawdą, jak ,pierwsza pożyczka bez opłat wstępnych”, „nie ponosisz opłat za udzielenie pożyczki, masz możliwość wcześniejszej spłaty” itp. Reklamy te naruszały zbiorowe interesy konsumentów, ponieważ odnosiły się tylko do niepobierania opłat w okresie przed zawarciem umowy i mogły sugerować konsumentom, że udzielenie pożyczki nie będzie związane z żadnymi kosztami.

Niebankowe firmy pożyczkowe stosują również zakazane nieuczciwe praktyki rynkowe (tzw. czarne praktyki rynkowe) wymienione w art. 7(2), u.p.n.p.r., do których przede wszystkim należą: posługiwanie się certyfikatem, znakiem jakości lub równorzędnym oznaczeniem, nie mając do tego uprawnienia, prezentowanie uprawnień przysługujących konsumentom z mocy prawa, jako cechy wyróżniającej ofertę przedsiębiorcy. W obu przypadkach firmy, w opinii UOKiK, naruszyły prawo, Profi Credit powoływał się bowiem w reklamach na certyfikat wydawany przez program Rzetelna Firma, choć od roku 2012 nie uczestniczył w tym programie i nie był upoważniony do korzystania z Certyfikatu Rzetelności, natomiast Bezpieczna Pożyczka zaprezentowała konsumentom przysługujące im uprawnienia z mocy prawa (brak obowiązku wymeldowania, brak obowiązku przeniesienia własności nieruchomości, która ma stanowić zabezpieczenie spłaty pożyczki), mogące być cechą wyróżniającą ofertę tego pożyczkodawcy ${ }^{41}$.

Ustawa o kredycie konsumenckim w art. 7 nakłada na kredytodawcę obowiązek przedstawienia w sposób jednoznaczny, zrozumiały i widoczny w reklamach dotyczących kredytu konsumenckiego danych dotyczących kosztu kredytu, chodzi tu przede wszystkim o: stopę oprocentowania kredytu wraz z wyodrębnieniem opłat uwzględnianych w całkowitym koszcie kredytu całkowitą kwotę kredytu, rzeczywistą roczną stopę oprocentowania oraz czas obowiązywania umowy, całkowitą kwotę do zapłaty przez konsumenta z wysokością rat, a także cenę towaru lub usługi oraz kwotę wszystkich zaliczek w wypadku umowy o kredyt przewidującej odroczenie płatności.

Badając reklamy firm pożyczkowych pod kątem wymogów art. 7 u.k.k., UOKiK przedstawił następujące zastrzeżenie — badane reklamy nie określały: stopy oprocentowania pożyczki wraz z wyodrębnieniem opłat uwzględnianych w całkowitym koszcie pożyczki, całkowitej kwoty pożyczki, RRSO, czasu obowiązywania umowy i całkowitej kwoty do zapłaty przez konsumenta (takie naruszenia art. 7 u.k.k. wykrył Urząd w firmie SILDEKs i FANT) ${ }^{42}$. Z interpretacji UOKiK art. 7 u.k.k. wynika, iż firmy pożyczkowe w reklamach przedstawiają koszty odnoszące się do wielu pożyczek, przez co uniemożliwiają ustalenie, która z opcji stanowi reprezentatywny przykład. W opinii Urzędu ważne jest, aby konsument, zapoznając się z reklamą, uzyskał konkretne informacje co do prezento-

40 Decyzja UOKiK nr RBG-20/2014.

41 Raport UOKiK, s. 31.

42 Ibidem, s. 35. 
wanych wartości i nie musiał domyślać się lub dodatkowo ustalać, jakie znaczenie mają użyte przez pożyczkodawcę pojęcia ${ }^{43}$.

\section{Zakończenie}

Mając na uwadze powyższy tekst, należy podkreślić, iż niebankowe firmy pożyczkowe, będąc profesjonalnymi spółkami, powinny znać przepisy wspomnianych powyżej aktów prawnych, które dotyczą warunków świadczenia usług finansowych, w tym w szczególności udzielania pożyczek konsumentom. Zważywszy na fakt, że konsumenci są „, słabszą” stroną na rynku w stosunku do przedsiębiorców, powinni otrzymywać od nich rzetelne dane o całkowitej kwocie do zapłaty, która powinna być podana na dzień zawarcia umowy. Podawanie przez pożyczkodawców innej sumy całkowitego kosztu pożyczki w umowach skutkuje pozbawieniem konsumenta podstawowej informacji o cenie otrzymanej pożyczki. Dlatego na UOKiK spoczywa kontrola firm udzielających pożyczki w kwestii ochrony konsumentów przed sprzecznymi z prawem ich działaniami na rynku usług finansowych. UOKiK w ramach swoich kompetencji administracyjnych monitoruje działania tych firm, sprawdza umowy zawierane z konsumentami oraz wydaje decyzje o konieczności zaprzestania ich działań, a nawet nakłada wysokie kary finansowe. Dla stwierdzenia, że dana praktyka stosowana przez firmy pożyczkowe wobec konsumentów jest sprzeczna przede wszystkim z ustawą o ochronie konkurencji i konsumentów wystarczy wykazanie, że potencjalnie istniało zagrożenie naruszenia interesów konsumentów na przykład wskutek niedopełnienia obowiązku informacyjnego i nie jest konieczne faktyczne wystąpienie negatywnego skutku w praktyce.

Oceniając funkcję, jaką pełni Urząd w ochronie konsumentów przed działaniami niebankowych firm pożyczkowych, należy podkreślić, iż dzięki wszczętym postępowaniom oraz nakładanym karom finansowym szkodliwość świadczonych konsumentom i sprzecznych z prawem usług maleje. W opinii UOKiK kary finansowe pełnią trojaką funkcję: represyjną, prewencyjną i edukacyjną. Nakładane przez Urząd kary finansowe mają powstrzymać przedsiębiorców przed stosowaniem zabronionych praktyk w obrocie $\mathrm{z}$ konsumentami i zniechęcić innych do stosowania praktyk naruszających wspomniane powyżej przepisy.

Reasumując, należy podkreślić, że dzięki działaniom UOKiK minimalizowane są obszary zagrożeń konsumentów przed praktykami stosowanymi przez niebankowe firmy pożyczkowe, w szczególności dotyczące: stosowania niedozwolonych postanowień umownych, pobierania opłat za dokonywane czynności przekraczających pułap wynikający z przepisów prawa, wprowadzanie konsumentów w błąd przez zamieszczanie reklam mogących zniekształcić zachowania rynkowe przeciętnego konsumenta, a przede wszystkim notoryczne oszukiwanie konsumentów co do całkowitego kosztu kredytu.

43 Ibidem, s. 38. 


\section{Bibliografia}

Bączyk M., Góral L., Fojcik-Mastalska E., Pisuliński J., Pyzioł W. (red.), (2007), Prawo bankowe. Komentarz, Warszawa.

Bednarek M., Samcik M., Parabanki rosna w siłe, „Gazeta Wyborcza” 15.08.2012.

Łętowska E. (2002), Prawo umów konsumenckich, Warszawa.

Masiukiewicz P. (2011), Regulacja a ryzyko shadow banking $w$ Polsce, [w:] Prace i Materiaty Wydziału Zarzadzania Uniwersytetu Gdańskiego, Gdańsk.

Olszak M. (2008), System bankowy oraz parabankowy w Polsce, Warszawa.

Raport UOKiK z kontroli reklam pozabankowych instytucji finansowych oferujących pożyczki konsumentom, Warszawa 2013.

Srokosz W. (2011), Instytucje parabankowe w Polsce, Warszawa.

Szpringer W. (2012), Problem parabanków na tle pojęcia banku jako instytucji kredytowej w Unii Europejskiej, „Prawo Bankowe” 11.

Waliszewski K. (2012), Miejsce i rola parabanków w systemie finansowym i gospodarce, Warszawa.

\section{Akty prawne}

Konstytucja Rzeczypospolitej Polskiej z dnia 2 kwietnia 1997 r., Dz.U. z 1997, poz. 483.

Ustawa o ochronie konkurencji i konsumentów z dnia 16 lutego 2007 r., Dz.U. Nr 50, poz. 331.

Ustawa o zmianie ustawy o ochronie konkurencji i konsumentów z dnia 10 czerwca 2014 r. z Dz.U. z 2014 r. poz. 945.

Ustawa o zwalczaniu nieuczciwej konkurencji z dnia 16 kwietnia 1993 r. Dz.U. Nr 47 z 1993 r., poz. 211 z późniejszymi zmianami z 2009 r., Dz.U. z 2009 r., Nr 201, poz. 1540.

Ustawa o przeciwdziałaniu nieuczciwym praktykom rynkowym z dnia 23 sierpnia 2007 r., Dz.U. $\mathrm{Nr} 171$ z 2007 r., poz. 1206.

Ustawa o kredycie konsumenckim z dnia 12 maja 2011 r., Dz.U. z 2014 r., poz. 1479, 1585, 1662.

Ustawa o zmianie ustawy o ochronie konkurencji i konsumentów oraz niektórych innych ustaw z dnia 5 sierpnia 2015 r., Dz.U. z 2015 r. poz. 1634.

Ustawa o zmianie ustawy o nadzorze nad rynkiem finansowym oraz niektórych innych ustaw z dnia 5 sierpnia 2015 r., Dz.U. z 2015 r. poz. 1357, 1830.

\section{Decyzje UOKiK i wyroki SOKiK}

Decyzja UOKiK nr RWR 61-29/12.

Decyzja UOKiK nr RGD-61-12/13 MLM.

Decyzja UOKiK nr RBG-10/2014, RBG-61-20/13/KL.

Decyzja UOKiK nr RBG-20/2014.

Decyzja UOKiK nr RKT-61-01/14/BP.

Decyzja UOKiK nr RWA - 61-5/201.

Decyzja UOKiK nr RŁO 3/2015.

Decyzja UOKiK nr RBG- 20/204/2015.

Wyrok SOKiK, sygn. akt XVII AmA 46/04.

Wyrok SOKiK, sygn. akt AmA 118/04.

Wyrok SOKiK, sygn. akt XVII AmC 1162/09.

Wyrok SOKiK, sygn. akt VI ACa 591/14.

Wyrok SN, sygn. akt I CSK 796/10.

Ekonomia - Wroclaw Economic Review 22/1 (2016)

(C) for this edition by CNS 